\title{
OS RECURSOS DE PODER DO SINDICALISMO PORTUGUÊS
}

\author{
THE POWER RESOURCES OF PORTUGUESE TRADE UNIONISM
}

Hugo Dias ${ }^{1}$

\section{RESUMO}

As transformações ocorridas nas últimas três décadas produziram um contexto global que é particularmente adverso à ação sindical. Mas no caso dos países do sul da Europa - países periféricos integrados na zona Euro o período mais recente, caracterizado pela implementação de políticas de austeridade, constitui um marco essencial que buscou efetuar mudanças estruturais na esfera das relações de trabalho. O presente trabalho pretende estudar a evolução do movimento sindical português utilizando o quadro teórico dos recursos de poder. O estudo está dividido em quatro partes: primeiro, fornece-se uma visão panorâmica da economia, relações de trabalho e sindicalismo; segundo, analisa-se o processo de integração europeia assimétrica e a implementação das políticas de austeridade (2011-2015); terceiro, estuda-se o novo contexto político produzido pelas eleições legislativas de 4 de outubro de 2015; por fim, avançam-se algumas considerações sobre a evolução dos recursos de poder do sindicalismo português.

Palavras-chave: Portugal. Recursos de poder. Austeridade. Sindicalismo.

\begin{abstract}
Transformations in the last three decades have produced a global context that is particularly adverse to trade union action. But in the case of the countries of southern Europe - peripheral countries in the euro zone - the most recent moment, characterized by the implementation of austerity policies, constitutes an essential framework that sought to effect structural changes in the sphere of labour relations. The present work intends to study the evolution of portuguese trade unionism using the theoretical framework of power resources. The study is divided into four parts: first, it gives a panoramic view of the economy, labour relations and trade unionism; second, analyzes the process of asymmetric European integration and the implementation of the austerity policies (2011-2015); third, studies the new political context produzed by the legislative election of October 4, 2015; finally, advances some considerations on the evolution of the power resources of Portuguese trade unionism.
\end{abstract}

Keywords: Portugal. Power resources. Austerity. Trade unionism.

\section{INTRODUÇÃO' ${ }^{2}$}

Quatro de outubro de 2015 constitui um marco recente na vida política portuguesa. As eleições legislativas realizadas nessa data permitiram viabilizar uma solução governativa que retirou do poder a coligação de direita, composta pelo Partido Social Democrata (PSD) e pelo Partido Popular (CDS-PP). Embora as políticas de austeridade tenham começado em março de 2010, ainda sob a égide de um governo do Partido Socialista (PS), esta coligação, vencedora das eleições de 5 de junho de 2011, será responsável pelo período mais violento da sua implementação, sob os auspícios do Memorando de Entendimento assinado com a Troika,

\footnotetext{
${ }^{1}$ Professor da Unicamp e pesquisador do Centro de Estudos Sindicais e de Economia do Trabalho (CESIT) e do Centro de Estudos Sociais da Universidade de Coimbra. E-mail: hugo.rodrigues.dias@gmail.com

2 Este trabalho faz parte do projeto de investigação em curso intitulado "Reconstruindo o poder sindical na era da austeridade: três setores em análise", sediado no Centro de Estudos Sociais da Universidade de Coimbra, e tem o apoio financeiro da Fundação para a Ciência e Tecnologia (FCT/MEC) através de fundos nacionais, e é cofinanciado pelo Fundo Europeu de Desenvolvimento Regional (FEDER) através do Programa Operacional Competitividade e Inovação COMPETE 2020 no âmbito do projeto «PTDC/IVC-SOC/3533/2014 - POCI-010145-FEDER-016808».
} 
composta pelo Fundo Monetário Internacional (FMI), Banco Central Europeu (BCE) e Comissão Europeia (CE), em maio de 2011.

O resultado da eleição gerou uma nova composição da Assembleia da República ${ }^{3}$ em que a coligação de direita perdeu a maioria de deputados, abrindo espaço para um entendimento entre quatro partidos de centro-esquerda e esquerda - Partido Socialista (PS), Bloco de Esquerda (BE), Partido Comunista Português (PCP) e Partido Ecologista "Os Verdes" (PEV). O acordo assinado viabilizou a formação de um novo governo - a "Geringonça"" - composto apenas pelo PS, mas com apoio parlamentar dos demais partidos de esquerda.

A "Geringonça" assinala, de fato, uma ruptura com o passado mais recente, inaugurando um novo momento político, não só pela nova dinâmica de negociação parlamentar entre os quatro partidos que sustentam a solução governativa, mas porque o acordo firmado assumia o compromisso de inverter as políticas de austeridade implantadas no país que engendraram o empobrecimento da maioria da população, através da reversão de cortes nos salários e pensões e da redução da carga tributária, características do período anterior. O presente texto, no entanto, não visa estudar os contornos completos deste entendimento e, em que medida esta solução governativa constitui uma alternativa global às políticas de austeridade no contexto de um país periférico pertencente à União Europeia e à sua União Econômica e Monetária.

Pretende-se, de forma mais modesta, fazer uma aproximação ao estudo do movimento sindical português nesse novo contexto. Para tal, é tributário de duas referências teóricas principais. Em primeiro lugar, do programa de pesquisa desenvolvido, ao longo das últimas décadas, no Centro de Estudos Sociais da Universidade de Coimbra, que caracteriza Portugal enquanto sociedade de desenvolvimento intermédio ou semiperiférico no contexto europeu, procurando mobilizar um arsenal teórico com vista a tornar "inteligível" essa sua inserção. Mais recentemente, o trabalho desenvolvido pelo seu Observatório sobre Crises e Alternativas (CRISALT) constitui um marco de contra peritagem face ao discurso da inevitabilidade das políticas de austeridade. Deste são retiradas muitas das informações e análises que, aqui, constam e utiliza-se, em termos econômicos, a periodização de José Reis (2018) que identifica a existência, desde a década de 1960, de diferentes ciclos de crescimento econômico - ciclo da industrialização limitada (1960-1974), ciclo da democracia (1975-1983), ciclo da integração europeia (1984-1992), ciclo de integração monetária (1993-2002) e ciclo de instabilidade duradoura (2003-...) - aos quais vão corresponder determinadas formas de economia política.

A segunda referência teórica relaciona-se, mais especificamente, com os estudos sobre relações de trabalho e sindicalismo. As transformações econômicas, políticas e institucionais que ocorreram nas últimas três décadas produziram um contexto global que é particularmente adverso para a ação sindical. No entanto, em vez de tomar o sindicalismo como um expectador passivo da atual situação, os estudos de revitalização sindical produzem uma análise sensível ao contexto específico de atuação dos sindicatos, mas que enfatiza a sua "capacidade estratégica" e de "aprendizagem organizacional" (HYMAN, 2001, 2007) e as

\footnotetext{
3 Portugal é uma República Constitucional semipresidencial, que elege diretamente o Presidente da República e a Assembleia da República. A Assembleia da República é composta por 230 deputado/as, eleito/as em 22 círculos plurinominais em listas de partidos. O Governo da República necessita do apoio da Assembleia da República para governar, o que implica a aprovação do seu programa e do orçamento de Estado em sede parlamentar.

${ }^{4}$ Geringonça, segundo o dicionário é uma palavra corrente em Portugal para designar: "1) uma construção pouco sólida e que se escangalha facilmente; caranguejola; 2) um aparelho ou máquina considerada complicada; engenhoca; 3) uma coisa consertada que funciona a custo" (INFOPÉDIA, 2018). Foi primeiro utilizada de forma pejorativa para designar o novo acordo de Governo por Vasco Pulido Valente, um conhecido colunista de direita, e popularizada por Paulo Portas, Presidente do CDS-PP e vice-primeiro-ministro entre 2011 e 2015, na sessão em que o programa de governo da coligação de direita foi rejeitado (10 de novembro de 2015).
} 
dimensões e estratégias de revitalização (FREGE e KELLY, 2004). No presente caso, optou-se por utilizar o referencial teórico dos recursos de poder, que combina a noção de "escolha estratégica" dos sindicatos com os diferentes recursos de poder - estrutural, associativo, institucional e social - que este possui e pode acionar num determinado momento (SCHMALZ e DORRE, 2014; SCHMALZ, LUDWIG e WEBSTER, 2018).

A hipótese que orienta o texto é que nas últimas décadas ocorreram profundas mudanças nas bases de poder do trabalho organizado (DIAS e FERNANDES, 2016). Se no ciclo da industrialização limitada (1960-1974) houve mobilização dos trabalhadores com um sindicalismo tutelado, o ciclo da democracia (1974-1983) constituiu o seu momento áureo. O traço mais característico dos ciclos subsequentes - integração europeia (1984-1992) e integração monetária (1993-2002) - foi de enfraquecimento do seu poder associativo. No período mais recente (2003-...), com maior incidência entre 2011 e 2015, verificou-se um enfraquecimento do poder estrutural e do poder institucional, parcialmente contrariado pelo recurso desigual a formas de poder social. O momento político atual, embora não constitua uma ruptura com a economia política predominante no país e na União Europeia, criou uma nova estrutura de oportunidades políticas que permite ao sindicalismo português a possibilidade (incerta) do seu reforço, no curto prazo, mas que recoloca em cima da mesa os dilemas de uma revitalização da estratégia e da prática sindical que permita criar condições para transformações mais estruturantes e duráveis nos seus recursos de poder.

Para tal, o estudo divide-se em quatro partes: na primeira, procura-se fazer uma breve contextualização da trajetória da economia, das relações de trabalho e do sindicalismo, em torno de dois momentos históricos determinantes: a Revolução de 25 abril de 1974, e a adesão, em 1986, à Comunidade Econômica Europeia (atual UE); na segunda parte, analisa-se o processo de integração europeia assimétrica e a implementação das políticas de austeridade (2011-2015), bem como as respostas sindicais adotadas; na terceira parte, estuda-se o novo contexto político produzido pelas eleições legislativas de 4 de outubro de 2015; e, por fim, avançam-se algumas considerações sobre a evolução dos recursos de poder do sindicalismo português, com particular atenção ao período mais recente.

\section{UMA VISÃO PANORÂMICA DA ECONOMIA, RELAÇÕES DE TRABALHO E SINDICALISMO}

Portugal é, historicamente, uma sociedade de desenvolvimento intermédio ou semiperiférico inserida no contexto europeu (SANTOS, 1993). O golpe de Estado de 28 de maio de 1926 e a constituição do Estado Novo derrubou a $1^{\text {a }}$ República (1910-1926) e rompeu com um período que tinha assistido à consolidação do sindicalismo, ao seu protagonismo em lutas sociais e laborais e ao seu reconhecimento legislativo. O processo de "fascistização" do sindicalismo culmina com a aprovação, em 23 de Setembro de 1933, do Estatuto do Trabalho Nacional (ETN), e de um conjunto de Decretos que institui a criação de "sindicatos nacionais". No plano estritamente organizativo os sindicatos passariam a ser únicos, de inscrição obrigatória, de categoria profissional, e geograficamente fragmentados. Encontravam-se totalmente subalternizados em relação ao Estado, cuja tutela interferia sobre as eleições de direções sindicais e sua homologação, podendo, em última análise, dissolver a própria organização sindical (PATRIARCA, 1991) .

\footnotetext{
${ }^{5}$ A organização sindical mais importante da $1^{\text {a }}$ República (1910-1926) era a CGT, de pendor anarco-sindicalista, apesar da existência de outras forças como a Comissão Intersindical (afeta ao Partido Comunista Português, criado em 1921), Federação das Associações Operárias (socialistas) e Sindicatos Autónomos. Mas a repressão associada à entrada em vigor da lei das corporações, em 1934, teve como consequência a dissolução de quase todos os grupos sindicais autónomos em 1938.
} 
Embora as décadas posteriores não tenham sido desprovidas de conflitos e lutas laborais, da intervenção de forças oposicionistas na tentativa de ganhar eleições sindicais, ou de, pelo menos, incluir elementos nas listas únicas, o edificio sindical poucas modificações sofreu. Um elemento fundamental prende-se com a estratégia do Partido Comunista Português (PCP), formação política que, embora sofrendo forte repressão, manteve a sua organização clandestina e uma atividade permanente nas grandes aglomerações operárias. O PCP, inicialmente comprometido com a criação de organizações sindicais clandestinas, altera a sua orientação, apelando, a partir de 1941, à entrada nos sindicatos nacionais, aproveitando as oportunidades decorrentes do fato destes serem de inscrição obrigatória.

Apesar dos incentivos internacionais decorrentes da Grande Depressão de 1929 e do período após a $2^{\text {a }}$ Guerra Mundial, a dinâmica de industrialização somente se acelerará a partir de finais da década de 1950 e ao longo da década de 1960 (LAINS, 1994). Só em 1963 o valor do produto industrial ultrapassará o da agricultura e, apesar de taxas de crescimento do PIB elevadas entre 1950 e 1973, a industrialização foi incipiente e tardia. A industrialização, a partir da década de 1960, gerou zonas industriais, sobretudo em Lisboa e Setúbal, com elevada concentração operária propícia à organização sindical (PATRIARCA,1991; STOLEROFF, 2007).

A Primavera Marcelista ${ }^{6}$, do seu ensaio de liberalização política, em 1969, resultou um "afrouxamento" do controle direto do Estado sobre os sindicatos. O "aproveitamento total das novas margens de atuação" permitiu a conquista de cerca de 30 sindicatos por listas da oposição. Um momento incontornável da "reanimação sindical" é a convocatória das "reuniões intersindicais". Em 28 de Setembro de 1970, cinco direções sindicais de Lisboa decidem convocar uma reunião intersindical para dia 11 de outubro do mesmo ano ${ }^{7}$, convidando 19 sindicatos de todo o país, dos quais 14 comparecerem. Essas reuniões, inicialmente toleradas pelo regime, serão proibidas a partir de 26 de julho de 1971, passando a se realizarem na "quase clandestinidade" até à Revolução de 25 de abril (BARRETO, 1990, p. $57,92)$.

A Revolução de 25 de abril de 1974 constitui o marco histórico incontornável que permitiu o fim de quase cinco décadas de regime político autoritário que tinha moldado um país com uma industrialização limitada e com volumosa emigração - o ciclo da ditadura (1960-1974) (REIS, 2018, p. 85); uma economia dependente das matérias-primas e mercados das colônias; restrição das liberdades políticas e um sindicalismo tutelado pelo regime corporativo; e um regime de proteção social praticamente inexistente. "Em 25 de abril de 1974, Portugal era o país menos desenvolvido da Europa e ao mesmo tempo o detentor único do maior e mais duradouro império colonial europeu" (SANTOS, 1994, p. 58).

A Revolução de 25 de abril, e as suas aspirações de democratização política, econômica e social, marcará o ciclo econômico da democracia (1975-1983). Apesar de ser permeado por momentos políticos diferentes, o elemento unificador deste período é "uma relação intensa dos propósitos da democracia, acabada de conquistar, com a organização da economia que começa por determinar os processos de mudança. As instituições que configuram o sistema de emprego, a segurança social, a repartição do rendimento e o acesso à provisão de serviços coletivos tornam-se cruciais" (REIS, 2018, p. 51). Neste contexto, para além da organização da economia em função de propósitos de consagração de um projeto democrático, de promoção do bem-estar geral da população e de redução das desigualdades

\footnotetext{
${ }^{6}$ Marcello Caetano sucederá a António de Oliveira Salazar, em 1968, no cargo de Presidente do Conselho de Ministros. A Primavera Marcelista designa seu período inicial de governo, entre 1968 e 1970, em que se gerou a expectativa de uma modernização econômica e social e de uma liberalização política moderada, o que não chegou a se concretizar.

${ }^{7}$ A data do ofício de convocatória, 1 de Outubro, é considerada a data de nascimento da CGTP-IN, que ainda hoje mantém a designação Intersindical Nacional.
} 
sociais, o crescimento com geração de emprego foi o elemento determinante ${ }^{8}$, reduzindo-se praticamente a zero a emigração e tendo o país que receber mais de meio milhão de cidadãos residentes nos territórios africanos em descolonização (REIS, 2018, p. 52, 86).

No período entre o 25 de abril de 1974 e 25 de novembro de 1975, vulgo período revolucionário, assiste-se a uma profunda transformação legislativa no campo laboral e social sob forte pressão do movimento popular e sindical, que procura instalar uma relação salarial fordista próxima da dos países centrais (LIMA, 1991). Em março de 1975, o Governo Provisório, presidido por Vasco Gonçalves - pertencente à facção próxima ao Partido Comunista Português no Movimento das Forças Armadas - nacionaliza o setor bancário, a indústria, os transportes, e inicia o processo de reforma agrária.

Este novo contexto assinala, no entanto, uma assincronia histórica, pois, no exato momento em que se ensaia um modelo de relação salarial fordista e de Estado-providência em Portugal, este começava a entrar em crise nos países centrais. Uma característica específica da nova relação salarial é esta emanar, sobretudo, do campo político e desligada do contexto econômico. Segundo Santos, Reis e Marques (1986):

Só as condições políticas de então [...] tornaram possível a ruptura políticojurídica com o passado recente fosse tão nítida e que o Estado assumisse de modo tão decisivo e absorvente a regulação da nova relação salarial. Daí decorreram três consequências importantes. Em primeiro lugar, o novo modelo de regulação foi, em grande medida, imposto ao empresariado colocado numa posição defensiva e deficientemente organizado para poder negociar eficazmente o impacto das novas condições nas suas expectativas de lucro e de investimento. Em segundo lugar, os aumentos de salários e as demais transferências de rendimento implícitas na nova relação salarial foram decididas sem qualquer vinculação a eventuais ganhos de produtividade do trabalho e pelo contrário foram concomitantes de perdas de produtividade. Em terceiro lugar, à medida que se aprofundou a crise revolucionária, os direitos dos trabalhadores passaram a ser defendidos não em nome de uma nova ordem capitalista, como sucedera nos países centrais, mas em nome de uma transição para uma sociedade de tipo socialista (SANTOS, REIS e MARQUES, 1986, p. 611).

É possível afirmar que este é o momento áureo do sindicalismo português ${ }^{9}$. Por um lado, retém elevados níveis de filiação e densidade sindical, herança parcial do Estado Novo em que a filiação sindical era obrigatória, e as mobilizações operárias são constantes - greves, paralisações, saneamento de administradores -, na sociedade e no interior das empresas, muitas vezes à revelia das próprias direções sindicais. Por outro lado, a nova lei sindical de 1975 mantém o princípio da unicidade sindical e a CGTP-IN subsistirá como a única Central Sindical. Os "sindicatos nacionais" são, desde o 25 de abril, "tomados" e elegem novas direções. Dada a força e organização da corrente comunista, a maioria das direções sindicais e da CGTP-IN serão hegemonizadas pelo PCP, o que, com o tempo, gerará reações de outras correntes à sua esquerda, mas também das correntes sindicais afetas ao Partido Socialista e ao Partido Social Democrata (STOLEROFF, 2007, 2013).

Com o fim do período de crise revolucionária, a evolução do Estado seguiu no sentido de se tornar mais permeável aos interesses do poder econômico. No entanto, mesmo após o período mais conturbado, a primeira Constituição, datada de abril de 1976, consagra ainda o ideário de construção de uma sociedade socialista, com uma economia mista de mercado e um grande setor empresarial do Estado nacionalizado, enquanto que o Estado e os

\footnotetext{
${ }^{8}$ Ver Tabela 1, nos anexos, para a evolução do crescimento do PIB e do emprego entre 1974 e 2017.

${ }^{9}$ Ver Tabela 2, nos anexos, para a evolução da sindicalização e das greves entre 1974 e 2017.
} 
Governos sucessivos se encontravam comprometidos com um projeto político de democracia liberal e com a restauração do regime de acumulação. Aumenta, assim, o hiato entre as prescrições constitucionais e a prática, em que o Estado primava pelo seu absenteísmo na aplicação das leis. Como refere Santos (1993) tal resultava,

[...] de uma situação política em que, por um lado, o capital é demasiado fraco para impor a recusa de uma legislação fordista, mas suficientemente forte para evitar que ela seja efetivamente posta em prática e em que, por outro, os trabalhadores são suficientemente fortes para impedir a rejeição dessas leis, mas demasiado fracos para impor a sua aplicação. (SANTOS, 1993, p. 32).

No campo sindical, a principal transformação ocorrida correspondeu ao fim da unicidade sindical e à criação de uma nova central sindical - a União Geral de Trabalhadores (UGT) - resultado da agudização das diferenças entre a maioria comunista e outras correntes políticas (socialista, socialdemocrata) no seio do movimento sindical. Em 14 de fevereiro de 1976 é lançado o Movimento Carta Aberta, assinado por 29 direções sindicais. Em setembro de 1976, são revogadas as disposições sobre a "unicidade sindical", criando as condições formais para a emergência de uma nova central sindical. Em 28 e 29 de outubro de 1978, em Lisboa, 47 sindicatos ( 8 dos quais com estatuto de observador) aprovaram a Declaração de Princípios e os Estatutos da União Geral de Trabalhadores, tendo o seu $1^{\mathrm{o}}$ Congresso se realizado na cidade do Porto, a 29 e 30 de janeiro de 1979.

Uma das principais consequências do "cisma sindical" foi a existência de sindicatos com orientações político-ideológicas diversas que passaram a disputar a representação de um mesmo setor (STOLEROFF, 1995): a CGTP-IN assume um perfil de sindicalismo de contestação, enfatizando a sua natureza de classe, tendo como momento fundador a criação da sua antecessora Intersindical, ainda durante o Estado Novo; a UGT, por sua vez, privilegia um sindicalismo de participação, que visa promover a integração social dos trabalhadores (SANTOS, 2004, p. 171). Cada central sindical alargou o âmbito ou incentivou a criação de novos sindicatos com vista a poder suprir as suas falhas de cobertura e de representação sindical.

O ciclo da democracia (1975-1983) vai dar lugar ao ciclo da integração europeia (1984-1992) (REIS, 2018). A adesão, em 1986, à CEE (atual UE) completaria o processo de (re)inserção de Portugal no contexto internacional, concebida como uma forma de estabilização do regime democrático, face aos excessos revolucionários, e de "apanhar o comboio do desenvolvimento". O processo de acumulação de capital tinha sido interrompido com a fuga de capitais e a nacionalização de grupos econômicos, compreendendo indústrias, bancos e seguradoras, que passaram para a esfera do setor empresarial do Estado. Um elemento determinante, em termos econômicos, era a recomposição de grupos econômicos privados, com vertente industrial e financeira, que pudessem posteriormente absorver alguns setores e empresas do setor empresarial do Estado, que se começa a concretizar com o início das privatizações.

Assim, já na década de 1980 predominará a orientação estatal de redução do hiato entre o quadro institucional e a prática social. O desiderato da integração europeia será o discurso impulsionador da aproximação às formas de organização social, política e econômica dos demais países membros ${ }^{10}$. As mudanças ocorridas são, portanto, determinadas por

\footnotetext{
${ }^{10}$ Boaventura de Sousa Santos referir-se-á a esta nova orientação do Estado como "O Estado-como-imaginaçãodo-Centro". Santos enfatiza que o discurso deste Estado "deslegitima qualquer especificidade do desenvolvimento nacional que não se enquadre nos atuais objetivos do Estado (por exemplo, o setor empresarial do Estado ou a pequena agricultura familiar), alegando que contrariam os padrões de desenvolvimento europeu,
} 
circunstâncias externas da integração europeia, que aceleram a abertura comercial do país. Embora se mantenha ainda uma trajetória de crescimento econômico com "taxas de investimento elevadas (embora, em média, num patamar ligeiramente inferior), acréscimos de emprego (porém também ligeiramente menores) e redução da emigração" (REIS, 2018, p. 87), mesmo mantendo o mesmo peso da indústria no PIB, aprofundar-se-á a dependência produtiva.

Ainda em 1982, num governo da Aliança Democrática ${ }^{11}$ (AD), ocorre a primeira revisão da Constituição que, entre outras mudanças, flexibiliza a organização do sistema econômico. A crise econômica de 1983-85, durante o governo do Bloco Central ${ }^{12}$, presidido por Mário Soares, com a disseminação dos salários em atraso, teve um primeiro efeito desmobilizador e desorganizador na classe operária e no sindicalismo (STOLEROFF, 2013, p. 10). Em 1984, é criado o Conselho Permanente de Concertação Social - atual Comissão Permanente de Concertação Social do Conselho Econômico e Social -, com a perspectiva da normalização contratual. Tal fato pressupõe a existência de atores sociais organizados, representativos de interesses, disponíveis para a negociação e aceitação de um pacto social. No entanto, nem trabalho nem capital tinham uma tradição longa de negociação. O Estado assumiu um papel fundamental na sua implementação: desde logo na criação ou adaptação dos atores sociais existentes - no plano patronal, ao privilegiar setores da burguesia modernizadora face aos seus setores mais conservadores; no plano sindical, a tentativa de isolamento da CGTP, que adere mais tarde em 1987, face à UGT; bem como através da criação das instituições onde esse processo de diálogo social pudesse ser levado a cabo ${ }^{13}$.

Nos Governos do PSD (1985-1995) ${ }^{14}$, presididos por Aníbal Cavaco Silva, ocorrerão as transformações mais determinantes na relação salarial. Em primeiro lugar, a segunda revisão constitucional ${ }^{15}$, aprovada em 1989, elimina o princípio da "irreversibilidade das nacionalizações" e a "lei quadro das privatizações", define as condições para a alienação dos bancos e seguradoras, telecomunicações, energia, siderurgia, entre outros setores. Seguirse-á, até 1996, um plano intenso de privatizações de empresas do setor empresarial do Estado que constituíam tradicionais bastiões do sindicalismo português, sobretudo a metalurgia. A privatização, com a respetiva reestruturação empresarial e modernização tecnológica, incentivou a saída de trabalhadores mais velhos, via reformas antecipadas, e reduziu o número médio de trabalhadores por empresa. Algumas dessas empresas deixaram mesmo de existir alguns anos depois, mercê da concorrência internacional, ou pura e simplesmente pela migração dos grupos econômicos, que as adquiriram, do setor industrial para o setor financeiro e da grande distribuição.

A segunda transformação diz respeito à flexibilização da legislação laboral. Embora o "pacote laboral" tenha sido travado pela primeira Greve Geral conjunta entre a CGTP e UGT, realizada a 28 de março de 1988, tal não impediu a aprovação posterior de nova legislação avulsa, no sentido de facilitar a demissão e promover a "diversidade contratual".

não sendo, por isso, politicamente defensáveis" (Santos, 1993, p. 51). Segundo o autor esta visão despolitizaria o processo político interno, dado que as medidas a serem tomadas tendo em vista à integração deixavam de ser opções políticas para se tornarem em medidas técnicas inevitáveis em nome das exigências dessa mesma integração.

${ }^{11}$ Coligação de centro-direita, formada em 1979 pelo PSD, CDS-PP e pelo Partido Popular Monárquico (PPM) que vencem as eleições legislativas intercalares de 1979 e eleições legislativas gerais de 1980, e governam até 1983.

${ }^{12}$ Coligação pós-eleitoral entre o PS e o PSD, com base nos resultados das eleições legislativas de 25 de abril de 1983. Governou entre 1983 e 1985.

${ }^{13}$ Sobre as diferentes etapas de construção do Diálogo Social em Portugal, ver Costa, 1994.

${ }^{14}$ O PSD governou em minoria entre 1985-87 e com maioria absoluta nas legislaturas de 1987-91 e 1991-95.

15 Quaisquer alterações à Constituição necessitam de ser aprovadas por uma maioria de dois terços dos Deputados em efetividade de funções, pelo que normalmente foram viabilizadas pelos três partidos do "arco da governabilidade", mesmo não estando em funções governamentais - PS, PSD e CDS-PP. 
Esta situação criou as condições para uma crescente dualização do mercado de trabalho, em que o núcleo central da legislação laboral se mantinha intacto, mas cujas normas flexibilizadoras permitiam às empresas o recurso a contratos precários facilitando a flexibilidade numérica. Mais uma vez, a este processo é associada uma retórica modernizadora do país, de reestruturação organizacional e tecnológica com vista a fazer face à concorrência internacional e de aproximação ao modelo de organização econômica dos países da então CEE ${ }^{16}$.

O quarto ciclo econômico, da integração monetária (1993-2002), caracteriza-se por ser o momento de aprofundamento da integração europeia, não pela via da convergência real e da coesão, mas pela constituição de um mercado comum e, mais tarde, de uma União Econômica e Monetária (UEM). O Ato Único Europeu, que entrou em vigor em 1987, determinou a criação do Mercado Interno em 1992, com liberdade de circulação de mercadorias, serviços, pessoas e capitais. O Tratado de Maastricht, também de 1992, determinará os critérios de convergência nominal - estabilidade monetária, estabilidade cambial e controle das finanças públicas (déficit do orçamento em relação ao PIB inferior a 3\%; dívida pública em relação ao PIB inferior a 60\%) - no sentido da criação da moeda única.

O ciclo da integração monetária resultará num crescimento mais baixo e instável, e num aprofundamento da dependência e endividamento em relação ao exterior. Segundo José Reis, tal situação:

[...] deve-se ao novo quadro institucional dentro do qual a economia portuguesa passou a funcionar na segunda metade dos anos noventa. Esse quadro é o da UEM e o dos princípios de sujeição das economias a condicionalidades macroeconômicas nominais e da conjuntura. Estes reduzem o espaço das políticas públicas (por exemplo, das políticas cambial, orçamental $^{17}$, monetária, financeira, fiscal e de organização da produção e do mercado de trabalho) e protegem as relações de mercado, especialmente dos mercados financeiros, aos quais o próprio financiamento público e a política monetária se devem submeter (REIS, 2018, p. 59).

Dada a especificidade da situação portuguesa, o seu sindicalismo desenvolve-se também a contraciclo com o que se sucedia nos países centrais: 1) vive o período de ascensão da mobilização coletiva dos anos 1960 e início dos anos 1970 em regime autoritário; 2) durante a segunda metade da década de 1970, quando na Europa a concertação social tripartida era a regra, o sindicalismo português experimentou o momento de maior capacidade de mobilização e ação coletiva, sob a influência de um discurso classista que advogava a superação do capitalismo; 3) finalmente, a partir dos anos 80, quando os mecanismos de regulação macroeconômica entraram em crise, emergia o discurso neoliberal e o Estado procurava desregular e retirar-se do compromisso histórico de concertação social; assiste-se em Portugal à institucionalização da concertação social com a participação dos sindicatos então já em plena fase de flexibilização da relação salarial (SANTOS, 2004, p. 161-162).

No campo sindical é incontestável afirmar que os dois principais atores sindicais portugueses, ao longo deste período, continuaram sendo a CGTP-IN e a UGT, e os seus respectivos sindicatos. No entanto, acresce à divisão político-ideológica entre a CGTP e da UGT, duas outras clivagens. A primeira, com início em finais dos anos 70, opôs o

\footnotetext{
${ }^{16}$ Dentre a múltipla legislação aprovada, constituem marcos deste processo as primeiras leis que regulam a utilização de contratos a prazo e que permitem a criação de empresas de trabalho temporário. Ainda durante a década de 1990 outras leis aprofundarão a flexibilização: a Lei n ${ }^{\circ}$ 21/96 de 17 de Janeiro, que aumentou a flexibilidade interna através da versatilidade funcional e adaptabilidade do tempo de trabalho; Lei no 103/99 de 26 de Julho, que definiu o regime jurídico do trabalho a tempo parcial.

${ }^{17}$ Termo corrente em Portugal para designar "orçamentária".
} 
"sindicalismo de classe" ao sindicalismo "corporativista", ou seja, constituiu uma reação da parte de setores, face às práticas homogeneizadoras dos sindicatos. É o caso dos sindicatos de quadros técnicos, mas também de categorias profissionais como os pilotos da aviação civil ou maquinistas de transporte ferroviário. A segunda clivagem, posterior, e por vezes se cruzando com o movimento "corporativista", prende-se com a dinâmica de criação de sindicatos “independentes" em alternativa ao sindicalismo partidário da UGT e CGTP. É por isso que, da conjunção destes três elementos, e apesar de significativas reestruturações sindicais, com sucessivas fusões de sindicatos distritais em unidades geográficas mais amplas (multidistritos e nacional) o número de sindicatos permanece elevado, fragmentado e sobreposto (STOLEROFF, 2007; DIAS, 2012).

O número de sindicalizados e a densidade sindical atingem os valores mais elevados $(60,8 \%$ em 1978). Os valores decresceram paulatinamente, de forma mais abrupta na década de 1980 (de 53,5\% em 1981 para 28\% em 1990) e de forma mais lenta na década de 1990 (em 2000, 21,6\%). Verifica-se também, lentamente, uma alteração da composição

sociológica da sindicalização. À diminuição dos setores da indústria correspondeu o aumento do peso de empregados no setor dos serviços, mas, sobretudo, do setor público da administração central e local (STOLEROFF e NAUMANN, 2000, p. 6-7; MTSS, 2006, p. $68)$.

Por fim, a densidade sindical caracterizava-se também por uma fraca base organizativa ao nível da empresa (com exceção das grandes empresas e do setor público) e concentração dos recursos sindicais ao nível do setor ou de ramo, onde se realizava a negociação. Cumulativamente, o nível de conflitualidade social medido pela realização de greves, exceto a segunda metade da década de 1970, é baixo comparativamente com outros países da União Europeia e com níveis reduzidos de aceitação das reivindicações por parte dos empregadores (STOLEROFF, 1995; MTSS, 2006; COSTA, DIAS e SOEIRO, 2014).

Em síntese, se no ciclo da industrialização limitada ou da ditadura (1960-1974) haverá mobilização dos trabalhadores com um sindicalismo tutelado, o ciclo da democracia (1974-1983) constituirá o seu momento áureo. O traço mais característico dos ciclos subsequentes - integração europeia (1984-1992) e integração monetária (1993-2002) - será o de enfraquecimento do poder associativo, quer ao nível do local de trabalho, do setor de atividade e da sociedade em geral.

\section{A INTEGRAÇÃO EUROPEIA ASSIMÉTRICA E AS POLÍTICAS DE AUSTERIDADE}

Conforme foi referido anteriormente, o ciclo econômico de 1993-2002, já sob o signo do Mercado Interno e do cumprimento dos critérios de convergência nominal, com vista à participação na UEM, é marcado por crescimento mais baixo e instável e um aprofundamento da dependência e endividamento em relação ao exterior. Este já não seria um ciclo de crescimento como os três anteriores, mas um ciclo de passagem para uma nova economia política em que a característica predominante, desde 2003, seria a "instabilidade duradoura" (REIS, 2018, p. 90).

A União Europeia, com a sua nova arquitetura institucional baseada numa nova ortodoxia monetária e orçamentária, torna-se, segundo Streeck (2013), numa "máquina de liberalização". A UEM, mais especificamente, caracteriza-se por uma "economia política da integração assimétrica e da financeirização" (REIS, 2014). Segundo Reis (2014):

[...] a moeda única, desacompanhada de qualquer dos restantes mecanismos que são próprios da política econômica e social de uma zona soberana, 
desabrigou o conjunto da união e, muito particularmente, os países periféricos, que deixaram de dispor de políticas cambial, de controlo de capitais e de criação de crédito próprias e nem por isso passaram a ter políticas orçamentais, industriais, fiscais ou sociais comuns. O benefício deste processo foi para o capital financeiro europeu e para as frações mais internacionalizadas do capital industrial e, portanto, para os países onde se localizam e que não carecem do mesmo modo dos instrumentos de ação que faltam: assim se gerou uma assimetria estrutural europeia com consequências devastadoras para as periferias e, a prazo, para o próprio centro" (REIS, 2014, p. 11-12).

Assim, sem quaisquer mecanismos de compensação, a arquitetura da UEM agravará a fratura entre economias centrais e periféricas, entre credores e devedores, gerando consequentemente forte endividamento dos países do Sul da Europa. No entanto, ao contrário da narrativa que prevalecerá mais tarde, o endividamento não se relacionava com o financiamento do Estado, mas sim com dívida privada proveniente do sistema bancário. Em 2008 e 2009, logo após a eclosão da crise financeira internacional, a Comissão Europeia impulsionará uma política expansionista e de estímulos orçamentários. Mas, a partir de 2010, esta alterará a sua posição, adotando uma política de consolidação orçamentária, "centrada na redução dos papeis do Estado, e a ideia de "reformas estruturais", significando sobretudo processos de liberalização do mercado de trabalho e abaixamento dos custos salariais, passaram a ser a norma" (REIS, 2018, p. 64). Desta opção resultará não só os Programas de Estabilidade e Crescimento, a assinatura de Memorandos de Entendimento sobre as Condicionalidades de Política Econômica que viabilizam mecanismos de assistência financeira, mas também a implementação do Tratado sobre a Estabilidade, Coordenação e Governação na UEM (2012) que reforça os mecanismos de restrição orçamentária dos Estados-membros e suscita sucessivas recomendações por parte da Comissão Europeia de transformações legislativas nessas áreas.

A política de incentivo à flexibilização das relações laborais é também algo que persiste desde o início da década. A partir do ano 2000, com a Estratégia de Lisboa, é introduzido no léxico europeu das relações laborais o termo "flexigurança", inspirado na realidade dinamarquesa. No entanto, do triângulo virtuoso da flexigurança (mercado de trabalho flexível, políticas ativas de emprego, elevada proteção social), desenvolvem-se, sobretudo, as medidas de flexibilização do mercado de trabalho.

Em Novembro de 2003, entra em vigor um novo Código do Trabalho ${ }^{18}$ - cuja oposição tinha suscitado a Greve Geral de 10 de Dezembro de 2002, convocada pela CGTP contra o Governo PSD/CDS-PP liderado por Durão Barroso ${ }^{19}$ - que procedeu a uma

\footnotetext{
${ }^{18}$ Lei $\mathrm{n}^{\circ}$ 99/2003, de 27 de Agosto.

${ }^{19}$ Após três governos tendo como Primeiro-Ministro Anibal Cavaco Silva (PSD), as eleições legislativas de 1995 são vencidas pelo PS. Será o início de um ciclo de dois governos de maioria relativa (1995-1999; 1999-2002) liderados pelo Primeiro-Ministro António Guterres (atual Secretário-geral da ONU). O segundo governo não terminará a sua legislatura devido à demissão do Primeiro-Ministro após uma derrota eleitoral nas eleições locais. Em 17 de março de 2002, o PSD será o mais votado nas eleições legislativas, obtendo maioria absoluta para formar governo com uma coligação pós-eleitoral com o CDS-PP. O novo governo, chefiado por José Manuel Durão Barroso, toma posse a 6 de abril de 2002. Esta legislatura também não chegará ao fim. Durão Barroso demite-se em 17 de julho de 2004 para se tornar presidente da Comissão Europeia (2004-2014). A maioria PSD/CDS-PP no Parlamento viabilizou um segundo governo, conduzido por Pedro Santana Lopes que durou até o início de 2005, quando o Presidente da República, Jorge Sampaio, decidiu dissolver o parlamento e convocar eleições legislativas antecipadas para 20 de fevereiro de 2015. A 20 de março de 2005 tomará posse um governo de maioria absoluta do PS liderado por José Sócrates. Em 2009 o PS ganhará de novo as eleições legislativas, mas neste caso apenas com uma maioria relativa. José Sócrates tomará posse para um segundo governo que terminará com a sua demissão em 23 de março de 2011, mantendo-se em funções até 21 de junho, data de tomada de posse do governo PSD/CDS-PP, chefiado por Pedro Passos Coelho.
} 
sistematização da lei laboral portuguesa, dispersa por uma diversidade de diplomas, introduzindo igualmente mudanças significativas. O Código do Trabalho alarga a tipologia contratual e introduz duas alterações estruturantes: a alteração do princípio do tratamento mais favorável, o que permite que uma convenção coletiva possa conter disposições menos favoráveis que o estipulado na lei geral; e a introdução do regime da caducidade e da sobrevigência das convenções coletivas de trabalho, o que coloca os sindicatos numa situação difícil, dada a perda paulatina da sua representatividade e a relutância por parte das organizações patronais em favorecerem um clima de diálogo social que permita acordos de benefício mútuo.

A temática da flexibilização das relações laborais é retomada, no contexto da União Europeia pelo Livro Verde - "Modernizar o direito do trabalho para enfrentar os desafios do séc. XXI", que procura ligar a prossecução da Estratégia de Lisboa com a procura de instrumentos de regulação do direito do trabalho mais adequados ao aumento da competitividade do espaço europeu. As suas prescrições são concretas:

[...] o Grupo de Missão instou os Estados-Membros a avaliar o grau de flexibilidade previsto nos contratos clássicos, e, se necessário, proceder à sua alteração, no que diz respeito aos prazos de pré-aviso, custos e procedimentos aplicáveis ao despedimento ${ }^{20}$ individual ou coletivo, ou ainda no que se refere à definição do despedimento sem justa causa. (COMISSÃO EUROPEIA, 2006, p. 4)

Esta "recomendação" da Comissão Europeia encontrou eco nacional, e a nova maioria governativa do Partido Socialista (2005-2009), tendo José Sócrates como PrimeiroMinistro, reabre o Dossiê Laboral. Em 2006 é publicado o Livro Verde das Relações Laborais (MTSS, 2006), e em 2007 o Livro Branco (MTSS, 2007), que estaria na base da proposta de revisão do Código do Trabalho, apresentada a 22 de abril de 2008. Entretanto, ocorrerá outra Greve Geral (30 de maio de 2007) convocada pela CGTP, mas será finalmente aprovada pela Lei $n^{0}$ 7/2009, de 12 de fevereiro. Entre outras mudanças, pode-se destacar a introdução da figura do "despedimento por inadaptação", para além do "despedimento com justa causa", "despedimento por extinção do posto de trabalho" e " despedimento coletivo".

Se em 2008 e 2009 a Comissão Europeia adotou uma resposta expansionista, a partir de 2010 as políticas de austeridade instalam-se na sua plenitude. Em março de 2010 o Governo do PS anuncia o Programa de Estabilidade e Crescimento 2010-2013 (PEC-I), apontando para a deflação salarial como instrumento político, operando um corte radical do investimento público e estendendo o programa de privatizações. Foi no campo do trabalho que se verificaram os primeiros sinais do recrudescimento do protesto. A 29 de maio de 2010, uma manifestação promovida pela CGTP, torna-se numa das maiores realizadas, até então, no país. A greve geral de 24 de novembro de 2010, cuja motivação foi a oposição ao PEC-III, convocada conjuntamente pela CGTP e UGT, foi a primeira de uma série de cinco em menos de três anos (três em conjunto com a UGT).

O Governo procurou assinar um compromisso escrito com os parceiros sociais exceto a CGTP - e em 12 de março de 2011, no mesmo dia do protesto da "Geração à Rasca", anuncia um novo pacote de austeridade (PEC-IV). A dinâmica iniciada com a "Geração à Rasca" significou o alargamento dos protestos a outros setores sociais para além do campo sindical. Entretanto, o PEC-IV é rejeitado no Parlamento, pois o governo deixou de contar com o apoio parlamentar do PSD. Em 23 de março, o primeiro-ministro José Sócrates anunciou a sua demissão e em 6 de Abril formalizou o pedido de assistência financeira à

\footnotetext{
${ }^{20}$ Termo corrente em Portugal para designar "demissão".
} 
Troika, composta pela Comissão Europeia (CE), Banco Central Europeu (BCE) e o Fundo Monetário Internacional (FMI) (DIAS e FERNANDES, 2016, p. 44).

Com um governo demissionário, foram marcadas eleições legislativas para o dia 5 de junho de 2011. Mesmo antes da eleição, em 17 de maio é assinado o Memorando de Entendimento sobre as Condicionalidades de Política Econômica (2011), com a anuência do PS, PSD e CDS-PP e a oposição do PCP e Bloco de Esquerda. A eleição de 5 de junho ditará a vitória do PSD, que formará uma coligação pós-eleitoral com o CDS-PP, tomando posse o Governo, chefiado por Pedro Passos Coelho, em 21 de junho de 2011.

O Memorando de Entendimento determinava metas e mudanças nas mais diversas esferas. Em geral estas políticas podem se caracterizar como:

[...] políticas de desvalorização interna, significando isso o abaixamento dos custos unitários do trabalho, a alteração da repartição do rendimento, desvalorizando os salários, a redução dos custos públicos de reprodução social (na educação, na saúde e no funcionamento da administração), com forte privatização, e uma lógica de competitividade das exportações de bens e serviços assentes nos preços, os quais, inversamente, também deveriam reduzir as importações (REIS, 2018, p. 65).

Mas, ao contrário dos outros capítulos do memorando, onde as prescrições eram formuladas de forma genérica, as medidas relativas ao mercado de trabalho, eram enunciadas ao pormenor. "Nenhuma margem de discricionariedade era deixada para a concertação social ou para o legislador. As medidas pareciam ter saído, chaves-na-mão, de um repositório previamente existente que aguardava o momento oportuno para vir à luz do dia" (CASTRO CALDAS, 2015, p. 12).

A Lei n. ${ }^{\circ}$ 23/2012 procederá a uma nova alteração ao Código do Trabalho, a terceira modificação de vulto ocorrida em apenas uma década. Dentre outras medidas é possível destacar: aumento do tempo de trabalho não pago (redução do número de dias feriado; redução do período de férias; eliminação dos descansos compensatórios), a redução do preço pago por determinadas prestações de trabalho (redução das majorações do trabalho suplementar, vulgo horas extra; redução do preço do trabalho normal prestado em dia feriado; redução do preço da isenção de horário de trabalho) e a redução do custo da demissão e de outros casos de extinção do contrato (compensação por despedimento fundado em motivo não inerente ao trabalhador e a compensação por extinção de contrato a termo) (COSTA, 2015a).

Em termos econômicos, a estratégia da "desvalorização interna" gerou uma forte recessão. A balança de transações correntes diminuiu o seu deficit não só por causa do aumento das exportações, mas também pela diminuição das importações devido à enorme contração do mercado interno. Entre 2011 e 2013 o PIB recuará mais 7\%, para valores inferiores a 2001. No que diz respeito ao emprego, para além da compressão salarial e generalização da precarização, haverá destruição líquida de empregos e, mesmo com a emigração de mais de meio milhão de portugueses (2011-2015) - um ritmo apenas comparável ao da vaga migratória da década de 1960 - a taxa de desemprego, já elevada, passará de 12,7\% (2011) para 16,2\% (2013) (CASTRO CALDAS, 2015; REIS, 2018).

As políticas de austeridade inaugurarão também uma nova dinâmica de protesto. Alguns dos principais momentos de mobilização contra as políticas de austeridade como o protesto da "Geração à Rasca" (12 de março de 2011) e o movimento "Que se lixe a troika! Queremos as nossas vidas!" (principalmente as manifestações de 15 de setembro de 2012 e 2 de março de 2013), serão protagonizados por atores sociais não sindicais, o que levará os sindicatos a reequacionarem a sua relação com estes movimentos (DIAS e FERNANDES, 2016, p. 45). 
No campo sindical, proliferarão as ações de protesto, desde manifestações e greves. Face a uma abertura institucional cada vez menor, a mobilização política no espaço produtivo e no espaço público, e dentro destas, a greve geral política será a forma privilegiada, mesmo num contexto de enfraquecimento do seu poder estrutural e associativo. Assim, e conforme foi referido anteriormente, ocorreram cinco greves gerais entre 2010 e 2013, três das quais realizadas em conjunto pela CGTP e UGT - 24 de novembro de 2010, 24 de novembro de 2011 e 27 de junho de $2013^{21}$. "Juntar estruturas sindicais portadoras de ideologias distintas foi talvez o único "mérito" da austeridade. Isto é, a austeridade permitiu criar articulações em torno de interesses concretos, criando momentos de unificação de diferentes ideologias e correntes sindicais contra a ideologia do governo" (COSTA, 2015a, p. 13).

O período mais intenso deste ciclo de protesto termina em meados de $2013 \mathrm{com}$ a greve geral (CGTP e UGT) de 27 de junho de 2013. "A estratégia de derrube do governo não foi bem-sucedida e o desgaste de sindicatos e movimentos sociais conduziu a um processo de desmobilização social. Com o bloqueio das estruturas de oportunidades políticas, não se assistiu, desde então, a um recrudescimento da ação coletiva" (DIAS e FERNANDES, 2016, p. 50).

Em síntese, este período é caracterizado - com maior incidência entre 2011 e 2015 - pelo enfraquecimento do poder estrutural - com aumento do desemprego e do trabalho precário -, apesar do recurso a greves gerais políticas; e do poder institucional, através de amplas transformações na legislação laboral e do colapso da negociação coletiva. Este duplo enfraquecimento foi parcialmente contrariado pelo recurso desigual a formas de poder social, que se verificaram em determinados momentos do ciclo de protesto de 2010-2013.

\section{A “GERINGONÇA” E O NOVO CONTEXTO DE AÇÃO SINDICAL}

Entre o fim do ciclo mais intenso de protesto e as eleições legislativas de 4 de outubro de 2015 passarão mais de dois anos. Em junho de 2014 terminaria o programa de assistência financeira assinado com a Troika. O Governo procurará capitalizar a tímida recuperação da economia e redução do desemprego que ocorrem em 2014 e 2015, associando esses bons resultados aos sacrifícios feitos e à necessidade de manter esse rumo. Entretanto, após uma vitória tangencial do Partido Socialista nas eleições parlamentares Europeias de 2014 ( 25 de maio), gerar-se-á uma disputa pela liderança, que será vencida por António Costa, tornando-se, no final de 2014, no candidato do PS à chefia do Governo nas futuras eleições legislativas de 2015. O PS, no entanto, mesmo com a nova liderança, não conseguia se distanciar da coligação de direita nos estudos de opinião. Para tal, terá ajudado, sem dúvida, o fato do seu anterior Primeiro-Ministro e antigo Secretário-Geral, José Sócrates, estar envolvido num processo com a Justiça (ESTANQUE, COSTA e FONSECA, 2017).

Outro elemento presente no debate político em 2015 era o chamado "efeito Syriza"22. A coligação ainda no Governo apontará para a catástrofe desta situação, procurando reforçar a inevitabilidade das decisões políticas tomadas. O Partido Socialista procurará se distanciar desta questão, articulando um discurso de crítica às políticas de austeridade com a manutenção dos chamados "compromissos europeus". Os partidos à esquerda do PS verão com mais simpatia este desafio posto às instituições europeias, embora o Bloco de Esquerda e o Partido Comunista Português possuíssem avaliações muito diferentes do governo Syriza.

\footnotetext{
${ }^{21}$ Para um resumo das motivações das três greves gerais conjuntas ver Costa, Dias e Soeiro, 2014.

22 A coligação Syriza vence as eleições gregas de 25 de janeiro de 2015, com um programa de oposição às políticas de austeridade e de enfrentamento face à União Europeia. Num braço de ferro que se prolonga por cerca de seis meses, e após o referendo de 5 julho em que o povo grego na Grécia rejeitou a proposta de resgate financeiro proposta pelas instituições europeias, o governo de Alexis Tsipras será obrigado a aceitar termos ainda mais draconianos do que os inicialmente propostos.
} 
Na eleição de 4 de outubro de 2015, o PS não será o partido mais votado. A coligação Portugal à Frente, composta pelo PSD e CDS-PP, obteve 38,5\% dos votos e 107 mandatos. O PS obteve $32,3 \%$ e 86 mandatos. A grande novidade será mesmo o aumento da votação nos partidos à sua esquerda num contexto propício à concentração de voto útil no PS com vista a retirar a coligação de direita do poder. O Bloco de Esquerda obteve 10,2\% e 19 mandatos e a Coligação Democrática Unitária (CDU), formada pelo PCP e o Partido Ecologista "Os Verdes" (PEV), recolheu 8,3\% dos votos e 17 mandatos parlamentares ${ }^{23}$. Desta forma nenhum dos partidos ou coligações obteve maioria absoluta no parlamento, situação que obrigava à realização de negociações entre diferentes partidos para a viabilização de um Governo.

Neste contexto, a solução mais "óbvia" não era a da "Geringonça". O mainstream político defenderá que a coligação de direita formasse governo, mesmo em minoria. Era uma solução "costumeira" que necessitava que o PS viabilizasse o governo no parlamento. Mais tarde surgiram vozes em defesa da formação de um novo governo de "Bloco Central", composto pelos partidos da coligação de direita e pelo PS. No entanto, logo após a eleição os quatro partidos iniciaram negociações com vista a produzir um entendimento que evitasse que a coligação de direita voltasse ao poder. Em 19 de outubro, António Costa, secretário-geral do PS, rejeitou a proposta de formar um governo de coligação com a aliança de direita e, no dia seguinte, afirmou que o PS não viabilizaria no parlamento qualquer governo da coligação de direita, tendo transmitido ao Presidente da República, Aníbal Cavaco Silva, que o PS tinha condições para formar um governo apoiado no parlamento pelos demais partidos de esquerda.

Em 22 de outubro o Presidente da República indicou Pedro Passos Coelho, presidente do PSD e anterior primeiro-ministro, para formar Governo, mesmo sabendo que este não teria sustentação parlamentar. Em 10 de novembro, os quatro partidos assinam oficialmente os acordos de entendimento separadamente e aprovam no parlamento uma moção de rejeição ao programa de governo da coligação PSD/CDS-PP, fazendo com que este caísse. O XX Governo Constitucional durou apenas 27 dias. Em 24 de novembro António Costa foi indicado e em 26 de novembro de 2015 o XXI Governo Constitucional tomou posse.

A "Geringonça” é uma solução política sem precedentes no país. Nunca, desde a eleição do $1^{\circ}$ Governo Constitucional, em 1976, houve entendimentos à esquerda para viabilizar um Governo. A solução encontrou amplas simpatias no eleitorado de esquerda que muitas vezes criticava a dificuldade histórica dos partidos de esquerda em se entenderem, ao contrário do que acontecia com os dois partidos de direita ${ }^{24}$. Os acordos assinados permitiram a constituição de um governo do Partido Socialista com apoio parlamentar dos demais partidos signatários. Estes assentaram numa política de devolução de rendimentos, através da reversão das dimensões mais graves dos cortes de salários e de pensões e dos aumentos de impostos sobre rendimentos e numa política de aumento do salário-mínimo. Podem-se destacar, dentre outros aspectos: o cancelamento da privatização de algumas empresas públicas no setor dos transportes e a tentativa de reversão da privatização em curso da TAP; restituição de salários, pensões, férias e subsídios de $\mathrm{Natal}^{25}$; implementação de uma política de aumento do salário-mínimo, congelado desde 2009; reposição dos feriados nacionais suprimidos durante o período anterior; retorno à jornada de trabalho de 35 horas semanais na

\footnotetext{
${ }^{23}$ O Partido Pessoas-Animais-Natureza (PAN) elegeu pela primeira vez um parlamentar, com 1,4\%.

${ }^{24}$ Conforme foi referido anteriormente, não é propósito deste trabalho explorar os contornos mais estruturais e estruturantes da "Geringonça". Não convém, no entanto, subestimar as significativas diferenças políticas existentes entre os diversos partidos, e seria fundamental um estudo aprofundado da transformação do contexto político mais amplo que criou incentivos para esta aproximação, bem como do debate interno no seio dos diferentes partidos, e dos termos concretos da negociação realizada e da sua sustentação ao longo da legislatura. ${ }^{25} \mathrm{O}$ subsídio de Natal equivale ao $13^{\circ}$ salário, previsto na legislação trabalhista do Brasil.
} 
Administração Pública; criação de um seguro-desemprego para trabalhadores independentes ("recibos verdes") e medidas de combate à precariedade no setor público, com o compromisso de integrar "recibos verdes" 26 que exerçam funções permanentes (ESTANQUE, COSTA e FONSECA, 2017, p. 21-22).

Para além do cumprimento, por parte do Governo, dos compromissos assumidos, as demais matérias sobre as quais não havia acordo foram objeto de discussão em diversas instâncias. Em alguns casos estabeleceu-se uma metodologia de criação de grupos de trabalho, caso do acordo firmado entre PS e BE, mas foi, sobretudo na Assembleia da República em que estes debates ocorreram, nem sempre produzindo entendimentos comuns. Não obstante, a Assembleia da República revalorizou-se e a preparação do Orçamento de Estado tornou-se num momento fulcral de negociação de forma a que os acordos de princípio tivessem uma execução prática e enquadramento orçamentário.

Um tema que não gerou acordo entre os parceiros da "Geringonça" foi sobre as leis laborais. Enquanto que o PS reconhecia a necessidade de combater a precariedade (número excessivo de contratos a prazo e falso trabalho independente) e de relançar o diálogo social e a negociação coletiva, admitia apenas mudanças pontuais no Código do Trabalho de 2012, como no caso do banco de horas individual por mero "acordo" entre empregador e empregado (CAMPOS LIMA, 2017, p. 281; PARTIDO SOCIALISTA, 2015). Assim, nessas matérias, o Programa do XXI Governo Constitucional (2015) é em tudo semelhante ao Programa inicial que o PS apresentou nas eleições legislativas.

O Governo assumiu como orientação a negociação dessas matérias em sede de Concertação Social, enquanto que a CGTP, o BE e PCP defendiam uma revisão profunda do Código que revertesse algumas das mudanças ocorridas em 2002, 2009 e 2012 e argumentavam que a maioria de esquerda possuía plena legitimidade política para aprovar essas alterações na Assembleia da República. Assim, ao longo dos últimos anos o BE e o PCP fizeram sucessivas propostas no Parlamento, que foram sucessivamente recusadas com os votos contra do PS, PSD e CDS. Dentre as propostas feitas, estavam dois elementos centrais que equilibram a relação Capital-Trabalho e que tinham sofrido transformações desde 2002: o fim do princípio da caducidade das convenções coletivas, estabelecendo que estas não podem deixar de vigorar sem que haja uma nova convenção acordada, e a reposição na lei, como medida geral, do princípio do tratamento mais favorável ao trabalhador (DN, 2017).

Importa destacar duas medidas importantes aprovadas de combate à precariedade. O Grupo de trabalho para a elaboração de um Plano Nacional Contra a Precariedade decorrente do Acordo entre PS e BE, produziu um relatório, que embora finalizado em setembro de 2016, fora divulgado apenas em março de 2017 (GRUPO DE TRABALHO, 2016). Das medidas propostas neste Plano uma converte-se, em 19 de maio de 2017, na lei $55 / 2017$, que expande a lei de combate aos falsos recibos verdes (Lei 63/2013), aprofundando a ação especial de reconhecimento de contrato de trabalho ao trabalho não declarado, como os falsos estágios, o falso voluntariado, as falsas bolsas e o trabalho informal.

Igualmente, o Orçamento de Estado de 2016 incluía o compromisso de elaboração de estratégia plurianual de combate à precariedade, que conduziu a um levantamento de todos os instrumentos de contratação de natureza temporária na Administração Pública e no Setor empresarial do Estado, publicado em 31 de janeiro de 2017. Consequentemente a Lei do Orçamento de Estado para 2017 determinou a criação de um programa de regularização extraordinária dos vínculos precários na Administração Pública e no Setor Empresarial do Estado - PREVPAP. Numa primeira fase, até 30 de junho de 2017, os trabalhadores puderam

\footnotetext{
26 "Recibo verde" é um termo comum utilizado para designar trabalhadores independentes ou autônomos. O "recibo verde" corresponde ao documento emitido pelo trabalhador quando presta um serviço. A proliferação da sua utilização, tanto no setor público quanto no privado, gerou um debate sobre a necessidade de combater o falso trabalho autônomo.
} 
requerer a avaliação da sua situação. Posteriormente as chefias intermediárias puderam também identificar o número de precários em cada serviço, sendo os diversos requerimentos avaliados por Comissões de Avaliação Bipartite (CAB), constituídas por representantes ministeriais, dos serviços e das associações sindicais, com o objetivo de avaliar se as funções exercidas pelos trabalhadores correspondiam a necessidades permanentes e, se os vínculos jurídicos ao abrigo dos quais essas funções são exercidas eram adequados. Embora não tenha sido um processo pacífico, com resistência à integração desses trabalhadores por parte de diversas instituições, foram recebidos 31.957 requerimentos e, até ao momento, emitidos 7.101 pareceres das CAB aprovados e homologados pelo governo, e abertos 320 concursos para o preenchimento de 2.267 vagas (PREVPAP, 2018). Este processo tem, também, permitido a organização de coletivos de trabalhadores que, em torno da fiscalização do processo, ou da realização de denúncias de irregularidades, têm se mobilizado e organizado publicamente.

O Governo PS retomou a questão da reforma das Leis Laborais em 2018. Em 23 de março apresentou um conjunto de 27 propostas de alteração do Código que pretendia ver discutidas em sede de Concertação Social. O Ministro do Trabalho e da Segurança Social, Vieira da Silva, tinha já anunciado que não promoveria uma "reforma radical" da legislação laboral e, segundo ele, estas propostas visavam cumprir as promessas do Programa de Governo de combater a segmentação do mercado de trabalho, reforçar instrumentos de regulação e redinamizar a negociação coletiva. Estas propostas geraram tensões significativas no contexto da "Geringonça". BE, PCP e CGTP argumentaram que a maioria delas, longe de diminuírem a precariedade, a ampliavam. As associações patronais também criticaram as propostas e a UGT manteve-se disposta a negociar. O Acordo de Concertação Social, assinado em 30 de maio pelos diversos parceiros, exceto pela CGTP, continha modificações consideradas pelas Associações Patronais como positivas.

Desta forma, se por um lado, mantêm-se as propostas iniciais de restringir a duração máxima de contratos por tempo determinado (de três para dois anos) e temporários e de introduzir uma taxa de rotatividade - até $2 \%$ de contribuição adicional para a Segurança Social - para as empresas que mais recorrem a contratos a termo; por outro lado, são introduzidas algumas novidades que procuravam acomodar as reivindicações das associações patronais. Assim, apesar de se prever o fim do banco de horas individual, a negociação deste não passará necessariamente para a negociação coletiva, podendo ser objeto de acordos de grupo. Igualmente, propõe-se o alargamento do período experimental, de 90 para 180 dias, no caso de contratos sem prazo determinado celebrados com trabalhadores à procura do primeiro emprego e desempregados de longa duração. São ampliados também, de 15 para 35 dias, os contratos de muito curta duração. Se anteriormente, estes se restringiam apenas à atividade agrícola ou eventos turísticos, a proposta formulada permite potencialmente um alargamento do seu âmbito: "em situação de acréscimo excecional e substancial da atividade de empresa cujo ciclo anual apresente irregularidades decorrentes do respectivo mercado ou de natureza estrutural que não seja passível de assegurar pela sua estrutura permanente, nomeadamente em atividade sazonal no setor agrícola ou do turismo" (ECO, 2018).

O período mediado entre 30 de maio e 6 de julho de 2018 - a data inicial prevista para a votação no Parlamento das leis que viabilizariam o acordo de Concertação Social - foi pleno de eventos e de debates no espaço público. Em 9 de junho do mesmo ano, a CGTP realizou uma manifestação nacional em Lisboa, juntando milhares de trabalhadores, anunciando uma concentração à porta da Assembleia no dia da votação. Entretanto, ocorreram greves em diversos setores (ferroviário, comércio, saúde) e um conflito mais prolongado dos professores do Ensino Público. BE e PCP mantiveram a sua oposição, alegando que as propostas não combatiam a precariedade e mesmo o grupo Parlamentar do PS anunciou que apresentaria propostas de alteração visando "salvaguardar a melhor interpretação" do 
compromisso assinado em Concertação Social. A proposta foi aprovada na "generalidade", no dia 18 de julho, apenas com os votos favoráveis do PS, a abstenção do PSD, CDS-PP e PAN, e os votos contra do PCP, PEV e BE. Tramita ainda no Parlamento, sendo debatida em comissão especializada, até ser agendada votação final no plenário da Assembleia da República. Apesar de novas mobilizações sindicais, como foi o caso da manifestação realizada pela CGTP em 15 de novembro, e de promessas governamentais de realizar uma nova audiência pública sobre o tema, o plano do Governo é que estas propostas estejam em vigor no início de 2019.

\section{CONSIDERAÇÕES FINAIS}

A "Geringonça", com a sua política de devolução de rendimentos, contribuiu para uma retomada do mercado interno que, juntamente com a melhoria da balança de transações correntes, em virtude de um aumento significativo das exportações - sobretudo do turismo restaurou o crescimento econômico a níveis superiores a $2 \%$ ao ano e gerou uma diminuição mais acelerada do desemprego (de 12,4\% em 2015 para 8,9\% em 2017) ${ }^{27}$, gerando emprego em setores intensivos em mão de obra como comércio, restauração e hotelaria. Convém, no entanto, enfatizar que a "Geringonça" não rompe com nenhum dos condicionamentos estruturais da integração europeia assimétrica (REIS, 2018). A dívida externa e a governança europeia continuam a ser elementos de constrangimento para a construção de alternativas de política econômica. Os imperativos de redução do deficit do orçamento de Estado resultam em valores muito baixos de investimento público, sobretudo em serviços públicos como a saúde e educação (TELES, 2018). Isto significa que subsistem, no essencial, as formas de economia política, anteriormente referenciadas, que foram enfraquecendo o poder associativo, estrutural e institucional do sindicalismo.

No entanto o novo contexto propiciou a reabertura de espaços de interlocução política. Assim, o sindicalismo, para além de poder utilizar o seu tradicional repertório de ação coletiva pode também procurar influenciar o Parlamento e o Governo. Embora a UGT tenha privilegiado a Concertação Social, possui laços históricos próximos com o PS, enquanto que a CGTP, mais próxima do PCP, tem também respaldo político no BE. A "relativa abertura" dos canais de interlocução reforça, pelo menos neste ciclo político, o poder associativo do sindicalismo, num momento em que este atinge a mais baixa densidade sindical (16,1\%, em 2015). Não havendo, ainda, dados mais recentes disponíveis, é incerta a possibilidade de que os índices de sindicalização tenham recuperado desde então.

Em geral, verificou-se uma significativa diminuição das mobilizações sindicais nos primeiros dois anos de Geringonça - manifestações e greves. A política de devolução de rendimentos e o aumento do salário-mínimo começavam a fazer efeitos, não só na melhoria das condições de vida da maioria da população, bem como no crescimento da economia e na diminuição do desemprego - o que reforçou o seu poder estrutural. Assim, em 2017, os sindicatos, sobretudo da CGTP, começaram a aumentar as mobilizações, primeiro no setor público, em torno do descongelamento das carreiras de algumas categorias profissionais e da defesa dos serviços públicos, num contexto ainda de manutenção de uma política orçamentária restritiva. Em 2018, esta situação intensificou-se (professores, médicos, enfermeiros, entre outros) e alastrou-se para o setor privado em torno da revisão do Código do Trabalho e do restabelecimento de condições para a retomada da negociação coletiva ${ }^{28}$.

\footnotetext{
${ }^{27}$ A previsão do Governo e Banco de Portugal para o crescimento do PIB em 2018 é de 2,3\% enquanto que os dados mais recentes sobre o desemprego são de setembro de 2018 e apontam para uma taxa de desemprego de $6,6 \%$, o valor mais baixo desde setembro de 2002 (INE, 2018).

${ }^{28}$ Esta dinâmica ainda é apenas parcialmente captada pelas estatísticas da greve. Os dados oficiais mais recentes, referentes a 2017, apontam para uma inversão de tendência, que poderá se reforçar em 2018 e mesmo em 2019,
} 
A disputa em torno do Código do Trabalho é vital em termos do reforço do poder institucional do sindicalismo. Três sucessivas revisões flexibilizadoras abalaram os fundamentos nucleares do Direito do Trabalho, desequilibrando decisivamente a balança do poder em benefício do Capital. Cumulativamente, apesar do crescimento da economia e da baixa do desemprego, os salários reais médios mantiveram-se praticamente estagnados, resultado da criação de emprego, sobretudo em setores de baixa produtividade, mas também decorrente da estagnação do poder negocial dos trabalhadores (CASTRO CALDAS e RAMOS DE ALMEIDA, 2018; EXPRESSO, 2018). Como foi exposto, o Governo em questão pretendeu fazer o mínimo de alterações com base no entendimento de que esse desequilíbrio de poder não existe. Este tem sido o terreno fundamental de contenção em 2018 e também o será em 2019 antes das próximas eleições legislativas que fecham este ciclo político, em que o sindicalismo procurará utilizar o seu repertório de ação coletiva e de influência política. Mas, num contexto ainda amplamente desfavorável o sucesso desta orientação dependerá da mobilização de poder social.

Diversas reflexões têm apontado para os caminhos, mas também para as dificuldades de uma revitalização do sindicalismo português (COSTA, 2015b; STOLEROFF, 2013). Referindo-se, ainda, ao contexto de 2011-2015, Alan Stoleroff afirmava que:

[...] tanto o sindicalismo moderado, negociador e concertador como o sindicalismo intransigente, reivindicativo e militante estão a ver reveladas as falhas dos seus programas de ação: ao nível macro, nem a UGT está a conseguir parar a recessão com a sua política de concessões pactuadas, nem a CGTP está a conseguir aumentar a mobilização dos trabalhadores; ao nível micro, a indignação dos trabalhadores não pode traduzir-se em ação coletiva incisiva sem a sua organização efetiva e real nos locais de trabalho. Por outro lado, não há uma solução milagrosa ou sequer única para a revitalização sindical (STOLEROFF, 2013, p. 26).

Após uma episódica aproximação com dinâmicas de protesto social contra a austeridade, o sindicalismo parece ter retomado a sua prática sindical tradicional. As ações realizadas constituem o prolongamento de uma identidade sindical perfeitamente solidificada, em que se verifica pouca inovação no repertório tradicional utilizado, e pouca abertura dessas identidades à mudança de práticas. A debilidade da reflexão estratégica e a persistência de um discurso ou "ilusão de autossuficiência", preponderantes na ação sindical, faz com que estas organizações vejam com desconforto a emergência de novos atores políticos direcionados para a intervenção sobre as temáticas laborais e impedem o alargamento do seu campo de atuação, através da procura de alianças e coligações sustentadas numa estratégia de aproximação com setores precários da classe trabalhadora, normalmente mais afastados das lides sindicais (DIAS, 2012). Do retorno da estratégia e da construção de alianças sociais dependerá o reforço do seu poder social de forma a contribuir para mudanças de curto, mas, sobretudo, de longo prazo.

\section{REFERÊNCIAS}

dada a proliferação de episódios grevistas. Convém, no entanto, referir que as estatísticas oficiais excluem a Administração Pública, o que naturalmente subestima o impacto das greves nos mais diversos setores de atividade. 
BARRETO, J. Os primórdios da Intersindical sob Marcelo Caetano. Análise Social, Vol. XXV (1. $\left..^{\circ}-2 .^{\circ}\right),\left(\right.$ n. $\left.^{\circ} 105-106\right)$, p. 57-117, 1990.

CAMPOS LIMA, M. P. A grande regressão da negociação coletiva: os desafios e as alternativas. In: SILVA, M. C.; HESPANHA, P.; CASTRO CALDAS, J. (Coords.) Trabalho e Políticas de Emprego. Um retrocesso evitável. Coimbra: Conjuntura Actual Editora, 245$300,2017$.

CASTRO CALDAS, J. Desvalorização do trabalho: do Memorando à prática. Cadernos do Observatório, 6. Coimbra: Observatório das Crises e Alternativas, 2015.

CASTRO CALDAS, J; RAMOS DE ALMEIDA, J. Emprego e salários: pontos de interrogação. Barómetro das Crises, $\mathbf{n}^{0}$ 19. Coimbra: Observatório das Crises e Alternativas, 2018 .

COMISSÃO EUROPEIA, Green Paper - Modernising labour law to meet the challenges of the $21_{\text {st }}$ century, 2006.

COSTA, H. A. A construção do pacto social em Portugal. Revista Crítica de Ciências Sociais, 39, 119 - 146, 1994.

COSTA, H. A. Do contexto das reformas laborais às respostas do campo sindical. Cadernos do Observatório, 4. Coimbra: Observatório das Crises e Alternativas, 2015a.

COSTA, H. A. Le syndicalisme portugais et l'austérité : entre la force des protestations et la fragilité des alliances. Relations Industrielles / Industrial Relations, 70-2, 2015b, 262-284.

COSTA, H. A.; DIAS, H.; SOEIRO, J. As greves e a austeridade em Portugal: Olhares, expressões e recomposições. Revista Crítica de Ciências Sociais, 103, 173-202, 2014.

DIAS, H. Sindicalismo de Movimento Social? Experiências de renovação da prática sindical num contexto de transição de paradigma produtivo. (Tese de Doutoramento em Sociologia). Coimbra: Faculdade de Economia, 2012.

DIAS, H.; FERNANDES, L. A greve geral de novembro de 2012 e os protestos antiausteridade - análise a partir do caso português. International Journal on Working Conditions, 11, 37-54, 2016.

DN. Leis laborais. Governo fecha a porta a propostas do PCP e BE, 10 de fevereiro de 2017. Disponível em: <https://www.dn.pt/portugal/interior/leis-laborais-governo-fecha-aporta-a-propostas-do-pcp-e-be-5659943.html>. Acesso: 07.07.18.

ECO. O que muda na lei laboral em sete medidas, 31 de maio de 2018. Disponível em:

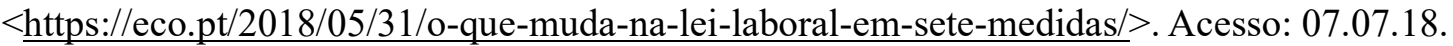

ESTANQUE, E.; COSTA, H. A.; FONSECA, D. Building the 'Contraption': Anti-austerity movements and political alternative in Portugal. In: Martinez, B. et al. (org.) Social Movements and the Radical Left. London: Routledge, 2017.

EXPRESSO. Salários devem aumentar para ajudar a recuperação económica, defende a OCDE, 4 de julho de 2018. Disponível em: <http://expresso.sapo.pt/economia/2018-07-04- 
Salarios-devem-aumentar-para-ajudar-a-recuperacao-economica-defende-a-

OCDE\#gs.U1hTVsI>. Acesso em: 07.07.18.

FREGE, C.; KELLY, J. Varieties of Unionism - strategies for union revitalization in a globalizing economy. Oxford: Oxford University Press, 2004.

GEP/MTSSS. Informação Estatística/Greves, 2016, 2018. Disponível em:

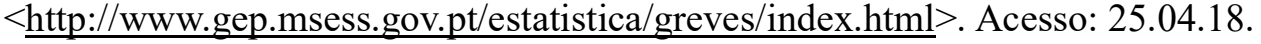

GEP/MTSSS. Livro Verde sobre as Relações Laborais, 2016. Disponível em: $<$ http://cite.gov.pt/pt/destaques/complementosDestqs2/LIVRO_VERDE_2016.pdf $>$. Acesso: 25.04.18.

GEP/MTSSS. Atualização do Livro Verde sobre as Relações Laborais 2016, 2018. Disponível em: $\quad<$ https://www.portugal.gov.pt/download-ficheiros/ficheiro.aspx? $\mathrm{v}=8 \mathrm{dfd} 193 \mathrm{e}-\mathrm{fe} 40-4960$ 9c5f-5dbd179556bc $>$. Acesso: 25.04.18.

GEP/MTSSS. Informação Estatística/Greves, 2017, 2018. Disponível em: $<$ http://www.gep.msess.gov.pt/estatistica/greves/index.html $>$. Acesso: 23.11.18.

GOVERNO DA REPÚBLICA; Comissão Europeia; Banco Central Europeu; Fundo Monetário Internacional. Memorando de Entendimento sobre as Condicionalidades de Política Económica, 2011. Disponível em:

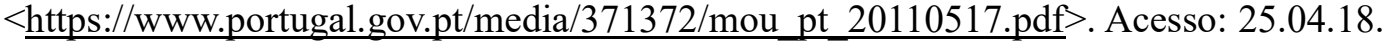

GOVERNO DA REPÚBLICA. Programa do XXI Governo Constitucional, 2015. Disponível em: $\quad\langle\underline{\text { https://www.parlamento.pt/Paginas/2015/novembro/Programa-do-XXI-Governo- }}$ Constitucional-entregue-na-Assembleia-da-Republica.aspx $>$. Acesso: 07.07.18.

GRUPO DE TRABALHO para preparação de um Plano Nacional contra a Precariedade. Relatório de Progresso, 2016.2 Disponível em:

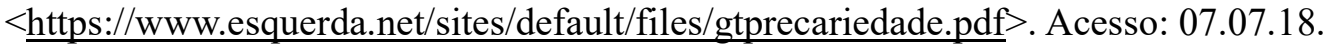

HYMAN, R. Understanding European Trade Unionism - between market, class and society. London: Sage, 2001.

HYMAN, R. How can trade unions act strategically? Transfer - European Review of Labour and Research, 13(2), 193-210, 2007.

INE. Estimativas Mensais de Emprego e Desemprego. Setembro de 2018. Disponível em: $<$ https://www.ine.pt/xportal/xmain?xpid=INE\&xpgid=ine destaques\&DESTAQUESdest bou $\underline{\mathrm{i}=315406339 \& D E S T A Q U E S t e m a=55574 \& D E S T A Q U E S m o d o=2}>$. Acesso: 29.11.18.

INFOPEDIA. Geringonça, $2018 . \quad$ Disponível em $<$ https://www.infopedia.pt/dicionarios/lingua-portuguesa/geringon $\% \mathrm{C} 3 \% \mathrm{~A} 7 \mathrm{a}>$. Acesso: 25.04.18.

LAINS, P. O Estado e a industrialização em Portugal, 1945-1990. Análise Social, vol. XXIX (128), p. 923-958, 1994.

LIMA, M. P. Relações de trabalho, estratégias sindicais e emprego (1974-90)", Análise Social, 114, 905-943, 1991. 
MTSS. Livro Verde Sobre as relações laborais. Lisboa, MTSS, 2006.

MTSS. Livro Branco Sobre as relações laborais. Lisboa, MTSS, 2007.

OCDE. Trade Union Membership and Trade Union Density, 2018. Disponível em:

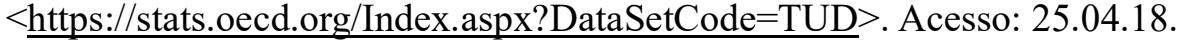

PARTIDO SOCIALISTA. Programa Eleitoral do Partido Socialista | Eleições Legislativas 2015. Disponível em: $<$ http://ps.pt/index.php/2018/04/06/programa-eleitoral-do-partidosocialista-legislativas-2015/>. Acesso: 07.07.18.

PATRIARCA, F. A institucionalização corporativa - das associações de classe aos sindicatos nacionais (1933). Análise Social, vol. XXVI (110),(1. ${ }^{\circ}$ ) p. 23-58, 1991.

PREVPAP. O que é o PREVPAP, Regularização extraordinária de vínculos laborais precários, 2018. Disponível em: < https://prevpap.gov.pt/ppap/index?windowId=991>. Acesso: 07.07.18.

REIS J., Apresentação. In: REIS, J. (Coord) A economia política do retrocesso - crise, causas e objectivos. Coimbra: Edições Almedina. 9-19, 2014.

REIS, J. A Economia Portuguesa - Formas de Economia Política numa Periferia Persistente (1960-2017). Coimbra: Edições Almedina, 2018.

SANTOS, B. S. O Estado, as relações salariais e o bem estar social na semiperiferia: o caso português. In: SANTOS, B. S. (org.), Portugal: um Retrato Singular. Porto. Edições Afrontamento. p. 17-56, 1993.

SAnTOS, B. S. Pela Mão de Alice: O Social e Político na Pós-Modernidade. Porto: Edições Afrontamento, 1994.

SANTOS, B. S. Teses para a renovação do sindicalismo em Portugal, seguidas de um apelo. In: ESTANQUE, E. et al. (Org.), Relações laborais e sindicalismo em mudança - Portugal, Brasil e o Contexto transnacional, Coimbra: Quarteto, 161-180, 2004.

SANTOS, B. S.; REIS, J.; MARQUES, M. M. L. O estado e as transformações recentes da relação salarial - a transição para um novo modelo de regulação da economia. Lisboa: CISEP-ISE, 1986.

SCHMALZ, S.; DORRE, K. The power resources approach. FES Project Trade Unions in Transformation, 2014.

SCHMALZ, S.; LUDWIG, C. e WEBSTER, E. The Power Resources Approach: Developments and Challenges. Global Labour Journal, 9(2): 113-134, 2018.

STOLEROFF, A., NAUMANN, R. As maiores organizações sindicais em Portugal: um quarto de século de evolução (comunicação) IV Congresso Português de Sociologia. Associação Portuguesa de Sociologia, 2000.

STOLEROFF, A. O Padrão de Relações Industriais emergente em Portugal. Organizações e Trabalho, 13, 11-42, 1995. 
STOLEROFF, A. Portuguese Trade Unionism: Dilemmas and Prospects. In: PHELAN, C. (ed.) Trade Union Revitalisation : Trends and Prospects in 34 Countries. Oxford, GBR: Peter Lang AG. p. 213-228, 2007.

STOLEROFF, A. A crise e as crises do sindicalismo: há uma revitalização possível? In: VARELA, R. A Segurança Social é Sustentável: Trabalho, Estado e Segurança Social em Portugal. Lisboa: Bertrand, p. 207-239, 2013.

STREECK, W. Tempo comprado - A crise adiada do capitalismo democrático. Coimbra: Actual, 2013.

TELES, N. The Portuguese Illusion. Jacobin, 2018. Disponível em: $<$ https://jacobinmag.com/2018/07/portugal-left-bloc-eurozone-austerity-eu $>$. Acesso: 07.07.18.

Recebido em 08 de outubro de 2018

Aceito em 07 de dezembro de 2018

\section{ANEXOS}

Tabela 1 - PIB, População empregada e desemprego, 1974-2017

\begin{tabular}{c|c|c|c|c}
\hline Ano & $\begin{array}{c}\text { Crescimento } \\
\text { real PIB (\%) }\end{array}$ & $\begin{array}{c}\text { População } \\
\text { Empregada } \\
\text { (milhares) }\end{array}$ & $\begin{array}{c}\text { Desemprego } \\
\text { (milhares) }\end{array}$ & $\begin{array}{c}\text { Taxa de } \\
\text { desemprego (\%) }\end{array}$ \\
\hline $\mathbf{1 9 7 4}$ & 2,91 & $3.694,0$ & 67,5 & --- \\
\hline $\mathbf{1 9 7 5}$ & $-5,1$ & $3.724,0$ & 179 & --- \\
\hline $\mathbf{1 9 7 6}$ & 2,29 & $3.789,0$ & 261,5 & --- \\
\hline $\mathbf{1 9 7 7}$ & 6,02 & $3.784,0$ & 309 & --- \\
\hline $\mathbf{1 9 7 8}$ & 6,17 & $3.772,0$ & 334 & --- \\
\hline $\mathbf{1 9 7 9}$ & 7,1 & $3.853,0$ & 344 & --- \\
\hline $\mathbf{1 9 8 0}$ & 4,76 & $3.924,5$ & 331,5 & --- \\
\hline $\mathbf{1 9 8 1}$ & 2,17 & $3.969,0$ & 356,5 & --- \\
\hline $\mathbf{1 9 8 2}$ & 2,16 & $3.958,5$ & 316 & --- \\
\hline $\mathbf{1 9 8 3}$ & 0,97 & $4.352,8 *$ & $365,8 *$ & $7,6^{*}$ \\
\hline $\mathbf{1 9 8 4}$ & $-1,04$ & $4.288,2$ & 393,9 & 8,2 \\
\hline $\mathbf{1 9 8 5}$ & 1,64 & $4.269,7$ & 405,4 & 8,5 \\
\hline
\end{tabular}




\begin{tabular}{|c|c|c|c|c|}
\hline 1986 & 3,32 & $4.289,1$ & 393,6 & 8,3 \\
\hline 1987 & 7,63 & $4.405,8$ & 329,2 & 6,8 \\
\hline 1988 & 5,34 & $4.512,8$ & 272,9 & 5,6 \\
\hline 1989 & 6,65 & $4.613,2$ & 243,5 & 5 \\
\hline 1990 & 7,86 & $4.717,5$ & 231,1 & 4,6 \\
\hline 1991 & 3,37 & $4.857,4$ & 207,5 & 4,1 \\
\hline 1992 & 3,13 & $4.543,1 *$ & $194,1 *$ & $4,1^{*}$ \\
\hline 1993 & $-0,69$ & $4.457,6$ & 257,5 & 5,5 \\
\hline 1994 & 1,49 & $4.449,1$ & 323,8 & 6,8 \\
\hline 1995 & 2,31 & $4.415,9$ & 338,4 & 7,1 \\
\hline 1996 & 3,50 & $4.444,3$ & 344 & 7,2 \\
\hline 1997 & 4,43 & 4.530 & 324,1 & 6,7 \\
\hline 1998 & 4,79 & $4.848,4^{*}$ & $251,8^{*}$ & $4,9^{*}$ \\
\hline 1999 & 3,89 & $4.925,7$ & 225,7 & 4,4 \\
\hline 2000 & 3,79 & $5.041,3$ & 206 & 3,9 \\
\hline 2001 & 1,94 & $5.128,2$ & 214,2 & 4 \\
\hline 2002 & 0,77 & $5.128,2$ & 270,5 & 5 \\
\hline 2003 & $-, 0,93$ & $5.143,8$ & 340,4 & 6,3 \\
\hline 2004 & 1,81 & $5.062,3$ & 359,1 & 6,6 \\
\hline 2005 & 0,77 & $5.047,3$ & 414,1 & 7,6 \\
\hline 2006 & 1,55 & 5.079 & 420,6 & 7,6 \\
\hline 2007 & 2,49 & $5.092,5$ & 440,6 & 8 \\
\hline 2008 & 0,20 & $5.116,6$ & 418 & 7,6 \\
\hline 2009 & $-2,98$ & $4.968,6$ & 517,4 & 9,4 \\
\hline 2010 & 1,90 & $4.898,4$ & 591,2 & 10,8 \\
\hline 2011 & $-1,83$ & $4,740,1 *$ & $688,2 *$ & $12,7^{*}$ \\
\hline 2012 & $-4,03$ & $4.546,9$ & 835,7 & 15,5 \\
\hline 2013 & $-1,13$ & $4.429,4$ & 855,2 & 16,2 \\
\hline 2014 & 0,89 & $4.499,5$ & 726 & 13,9 \\
\hline 2015 & 1,82 & $4.548,7$ & 646,5 & 12,4 \\
\hline 2016 & 1,62 & $4.605,2$ & 573 & 11,1 \\
\hline 2017 & 2,64 & $4.756,6$ & 462,8 & 8,9 \\
\hline
\end{tabular}

Fonte: PORDATA.

* quebra de série.

Tabela 2 - Sindicalização e greves em Portugal, 1974 - 2017

\begin{tabular}{c|c|c|c|c}
\hline Ano & $\begin{array}{c}\text { N. }^{\circ} \\
\text { sindicalizados } \\
\text { (milhares) }\end{array}$ & $\begin{array}{c}\text { Densidade } \\
\text { sindical (\%) }\end{array}$ & N. greves & $\begin{array}{c}\text { N. }{ }^{\circ} \text { trabalhadores } \\
\text { em greve (milhares) }\end{array}$ \\
\hline
\end{tabular}




\begin{tabular}{|c|c|c|c|c|}
\hline 1974 & --- & --- & 313 & --- \\
\hline 1975 & --- & --- & 340 & --- \\
\hline 1976 & --- & --- & 367 & --- \\
\hline 1977 & --- & --- & 357 & --- \\
\hline 1978 & $1.486,8$ & 60,8 & 333 & --- \\
\hline 1979 & 1.500 & 60,1 & 381 & --- \\
\hline 1980 & 1.460 & 54,8 & 374 & --- \\
\hline 1981 & 1.420 & 53,5 & 756 & --- \\
\hline 1982 & 1.380 & 50,5 & 563 & --- \\
\hline 1983 & 1.340 & 47,2 & 532 & --- \\
\hline 1984 & 1.300 & 47,2 & 550 & --- \\
\hline 1985 & 1.225 & 44,6 & 504 & --- \\
\hline 1986* & 1.150 & 41,2 & 363 & 231,5 \\
\hline 1987 & 1.093 & 38,6 & 213 & 81,3 \\
\hline 1988 & 1.035 & 35 & 181 & 155,5 \\
\hline 1989 & 978 & 32 & 307 & 296,1 \\
\hline 1990 & 920 & 28 & 271 & 128,9 \\
\hline 1991 & 896 & 28,2 & 262 & 119,1 \\
\hline 1992 & 872 & 26,1 & 409 & 131,9 \\
\hline 1993 & 848 & 26,1 & 230 & 83,1 \\
\hline 1994 & 824 & 25,9 & 300 & 94,4 \\
\hline 1995 & 800 & 25,4 & 282 & 60,4 \\
\hline 1996 & 802,6 & 25,5 & 272 & 50,5 \\
\hline 1997 & 805,1 & 25,2 & 265 & 45,8 \\
\hline 1998 & 798 & 23,4 & 227 & 44,2 \\
\hline 1999 & 790 & 22,5 & 200 & 33,5 \\
\hline 2000 & 783 & 21,6 & 250 & 38,8 \\
\hline 2001 & 824 & 22,4 & 208 & 26,1 \\
\hline 2002 & 768 & 20,7 & 250 & 80,2 \\
\hline 2003 & 783,4 & 21,2 & 170 & 30,3 \\
\hline 2004 & 802,6 & 21,4 & 122 & 31,9 \\
\hline 2005 & 804,2 & 21,2 & 126 & 21,7 \\
\hline 2006 & 805,9 & 20,8 & 155 & 33,5 \\
\hline 2007 & 804,4 & 20,8 & 99 & 29,2 \\
\hline $2008 * *$ & 803 & 20,5 & --- & -- \\
\hline 2009 & 771 & 20,1 & --- & -- \\
\hline $2010 * * *$ & 739 & 19,3 & 123 & 70,8 \\
\hline 2011 & 694 & 18,3 & 88 & 58,4 \\
\hline 2012 & 665 & 18,5 & 127 & 92,3 \\
\hline 2013 & --- & --- & 119 & 70,4 \\
\hline
\end{tabular}




\begin{tabular}{r|r|c|c|c}
\hline $\mathbf{2 0 1 4}$ & 615 & 17 & 90 & 18,1 \\
\hline $\mathbf{2 0 1 5}$ & 595,7 & 16,1 & 75 & 11,8 \\
\hline $\mathbf{2 0 1 6}$ & --- & --- & 76 & 6,5 \\
\hline $\mathbf{2 0 1 7}$ & --- & --- & 106 & 19,5 \\
\hline
\end{tabular}

* A série cronológica a partir de 1986 abrange todos os setores de atividade econômica, à exceção da Administração Pública.

** Em 2008 e 2009 não foram produzidas estatísticas de greves, por insuficiente informação recolhida.

*** Dados de 2010 a 2016 apenas para Portugal Continental.

Fonte: Costa, Dias e Soeiro, 2014; GEP/MTSSS, 2018; OCDE, 2018. 